\title{
Ecosystem services, social interdependencies, and collective action: a conceptual framework
}

\author{
Cecile Barnaud $^{1}$, Esteve Corbera $^{2}$, Roldan Muradian $^{3}$, Nicolas Salliou $^{1}$, Clélia Sirami $^{1}, \underline{\text { Aude Vialatte }}^{1},{ }_{\text {Jean-Philippe Choisis }}{ }^{1}$, \\ Nicolas Dendoncker $^{4}$, Raphael Mathevet ${ }^{5,6}$, Clémence Moreau $^{1,5}$, Victoria Reyes-Garcia ${ }^{2,7}$, Martí Boada $^{2,8}$, Marc Deconchat $^{1}$, \\ Catherine Cibien $^{9}$, Stephan Garnier ${ }^{10}, \underline{\text { Roser Maneja }}^{2}$ and Martine Antona ${ }^{11,12}$
}

\begin{abstract}
The governance of ecosystem services (ES) has been predominantly thought of in terms of market or state-based instruments. Comparatively, collective action mechanisms have rarely been considered. This paper addresses this gap by proposing a conceptual framework that brings together ES, social interdependencies, and collective action thinking. We use an ES conceptual lens to highlight social interdependencies among people so as to reflect on existing or potential collective actions among them. This framework can also contribute to increasing people's awareness of their mutual interdependencies and thereby fostering, framing, or enriching collective action, in ways that take into account the diversity and complexity of ecological processes underlying human activities. Our approach can contribute in particular to agroecological transitions that require landscape level innovations and coordination mechanisms among land users and managers. The framework distinguishes three types of social interdependencies: (i) between ES beneficiaries and ES providers, (ii) among beneficiaries, and (iii) among providers. These social interdependencies are in turn analyzed according to four main dimensions that are critical for collective action: (i) cognitive framing of interdependencies, (ii) levels of organization, (iii) formal and informal institutions, and (iv) power relations. Finally, we propose a strategy to turn this framework into action in contexts of participatory action research, a strategy grounded on a number of methodological principles and tools that convey complexity and increase people's awareness of interdependencies in agrarian social-ecological systems.
\end{abstract}

Key Words: actionable framework; agroecological transition; concerted ecosystem service management; multistakeholder approach; participatory action research; rural landscapes; territorial management

\section{INTRODUCTION}

The concept of ecosystem services (ES), broadly defined as the benefits nature provides to people, has become a major concept to address environmental concerns and foster sustainable development (MEA 2005, Díaz et al. 2015). Following its success in scientific and political spheres, the ES concept is now diffusing into local management spheres, e.g., protected areas, watershed councils, or urban planning (Grêt-Regamey et al. 2017). One of the challenges for managers is to operationalize this concept in ways that are meaningful to local stakeholders and useful to foster sustainable management of social-ecological systems (SES). Because SES are complex and multiscalar, it is now admitted that polycentric governance is needed, combining a diversity of coordination mechanisms, relying not only on market and statebased mechanisms, but also on collective action mechanisms involving local stakeholders (Ostrom et al. 1994, Agrawal and Ostrom 2001, Folke et al. 2002, Meinzen-Dick et al. 2004, Ostrom 2010). And yet, governance tools currently derived from ES thinking rely mainly on market (e.g., carbon markets, mitigation banks) and state-based (e.g., subsidies) instruments, or on programs hybridizing both (Fletcher and Breitling 2012, ShapiroGarza 2013). Comparatively, ES governance based on collective action remains rarely explored, whether theoretically or empirically (Muradian et al. 2010, Stallman 2011, Muradian 2013, Kerr et al. 2014).
We address this gap by proposing a conceptual framework combining ES thinking and collective action. We suggest using an ES lens to highlight social interdependencies among people so as to reflect on existing or potential collective actions among them. Used to increase people's awareness of their mutual interdependencies, this framework could also contribute to fostering, framing or enriching collective action in ways that take into account the diversity and complexity of ecological processes underlying human activities.

This theoretical proposition should, in our view, contribute to accompany transitions toward more sustainable SES. One of its potential domains of application is agroecological transitions in agrarian SES. Agroecology, defined as biodiversity-based agriculture, requires indeed socio-technical innovations that use, coprovide, and preserve ES linked to ecological processes that occur not only at field and farm levels, but also at the landscape level (Duru et al. 2015). Agroecological transition therefore requires coordination among the multiple land users and managers shaping these landscapes.

The objectives of this paper are fourfold: (i) to outline why and how the concepts of ES and collective action can enrich each other, especially through the notion of social interdependencies; (ii) to identify, within the recent literature bridging social sciences with ES research, the advancements and remaining gaps on which

${ }^{1}$ DYNAFOR, Université de Toulouse, INPT, INRA, Toulouse, France, ${ }^{2}$ Institut de Ciència i Tecnologia Ambientals (ICTA), Universitat Autònoma de Barcelona (UAB), Barcelona, Spain, ${ }^{3}$ Universidade Federal Fluminense, Faculty of Economics, Rio de Janeiro, Brazil, ${ }^{4}$ Department of Geography, University of Namur, Belgium, ${ }^{5}$ CEFE, CNRS, Univ Montpellier, Univ Paul Valéry Montpellier 3, EPHE, IRD, Montpellier, France, ${ }^{6}$ French Institute of Pondicherry, UMIFRE 21 CNRS-MAEE, India, ${ }^{7}$ Institució Catalana de Recerca i Estudis Avançats (ICREA), Barcelona, Spain, ${ }^{8}$ Ecological and Earth Sciences Division, United Nations Educational, Scientific and Cultural Organization (UNESCO), Paris, ${ }^{9} \mathrm{MAB}$ France, Toulouse, France, ${ }^{10}$ Parc National des Cévennes, Florac, France, ${ }^{11}$ CIRAD, UPR Green, F-34 098, Montpellier, France, ${ }^{12}$ Green, Univ Montpellier, CIRAD, Montpellier, France. 
our proposition draws; (iii) to propose a conceptual framework that clarifies the relationships between ES, social interdependencies, and collective action; and (iv) to illuminate how this conceptual framework can be turned into action to foster or enrich collective action in contexts of participatory action research.

\section{HOW CAN ECOSYSTEM SERVICES AND COLLECTIVE ACTION ENRICH EACH OTHER?}

\section{Definitions}

ES have been recently defined by Harrington et al. (2010:2781) as the "benefits that humans recognize as obtained from ecosystems that support, directly or indirectly, their survival and quality of life." This definition that stresses the subjectivity of ES fits well with the constructivist perspective that we adopt in this paper, i.e., ES do not exist per se, but as subjective perceptions, socially situated and constructed (Latour 2004).

The ES concept has generated numerous debates and controversies (Barnaud and Antona 2014). In particular, some have argued that the ES concept promotes Western and utilitarian views of nature, which in turn can lead to the monetization and commodification of nature (Sullivan 2009, Spash 2011, Maris 2014). In this paper, we advocate for a critical but constructive approach. We acknowledge that the concept should not be taken for granted and that the abovementioned fears and critiques should be taken seriously (Kosoy and Corbera 2010, Barnaud and Antona 2014). However, we also acknowledge that the ES concept has generated a momentum among researchers and decision makers on the importance of biodiversity and ecosystems for societies (Díaz et al. 2015). It would thus be a pity not to explore the potential added value of the concept to support more sustainable SES management, investigating for example its potential to enrich collective action in natural resource management.

Collective action has been broadly defined as an "action taken by a group [...] in pursuit of members' perceived shared interests" (Scott and Marshall 2009:96). Key collective action theories refer to the sharing of benefits and costs of collective action for managing public and common-pool resources ${ }^{[1]}$ (Olson 1965, Ostrom 1990). In this paper, we define collective action as a voluntary process of cooperation among various stakeholders, users, and managers addressing a common ES management problem in a given territory ${ }^{[2]}$. Because it aims to include in decision making processes all the stakeholders potentially affected by decisions, it conveys emancipatory values of equity and social justice (Rawls 1997). However, collective action is not always appropriate and has inherent risks (social exclusion, loss of autonomy, individual strategic behaviors) and costs (transaction and monitoring costs in particular), as underlined by Ostrom et al. (1994). Furthermore, power asymmetries and conflicts of interest can impede collective action, which requires not only social learning, trust building, and mutual understanding (Pahl-Wostl et al. 2007), but also negotiation and conflict resolution processes (Leeuwis 2000, Barnaud et al. 2010).

\section{What can collective action bring to ES governance?}

Several arguments sustain the idea that collective action thinking and practice can enrich ES-based management approaches. First, ES management often requires collective action. Many ES are indeed public or common-pool resources whose management cannot rely only on market or state incentives (Muradian and Rival 2012). Cooperation can then be required for both the production and the sharing of ES. When ES are provided at the landscape level, e.g., water regulation or pollination, their production is improved by cooperation among the multiple land users and managers shaping that landscape (Opdam et al. 2016). Moreover, when there are trade-offs among ES, i.e., when the production of a given ES is detrimental to the production of another ES, this results in a conflict of interests between the beneficiaries of these ES. In many cases, such trade-offs arise without the stakeholders being aware of them (Rodríguez et al. 2006). And yet, as they generate winners and losers, they are related to social choices that should be made explicit and collectively negotiated (Barnaud and Antona 2014). Some programs of payments for ES actually rely on collective action, for example when payments are given to groups rather than to individuals (Kerr et al. 2014) or when there are direct negotiations between ES providers and beneficiaries to find mutual agreement (Depres et al. 2008).

Collective action theories can also be useful for elucidating the challenges involved in managing specific ES through collective action, especially ES that are not based on common-pool resources. First, when ES provision is characterized by uncertain cause-effect relationships (in the case of, e.g., insect pest regulation), the risks and costs of collective action increase. Second, when it is possible to substitute a given ES with humanmade technology, e.g., chemical pesticides, the motivation for collective action decreases. Third, social distance increases the transaction costs of coordination; this can explain why market and state-based mechanisms are more frequent than collective action when ES providers and/or beneficiaries operate at distant scales and locations (like in the case of, e.g., the ES of climate regulation). In conclusion, institutional insights on collective action can enrich our understanding of ES governance by highlighting both its potential and limits compared to other governance mechanisms.

\section{What can the ES concept bring to the field of collective action?}

Institutional theories on collective action have been largely developed using the concept of natural resource (Berkes 1989, Ostrom et al. 1994, Agrawal and Ostrom 2001, Leach and Fairhead 2001, Adams et al. 2003, Borrini-Feyerabend et al. 2004, Adger et al. 2005). Whereas resources usually refer to clearly identified goods such as irrigation water, grasslands, or forest products, the concept of ES highlights, in addition, other types of benefits that are more diverse (from, e.g., insect pest control to patrimonial landscapes), less visible (e.g., pollination, air quality), and more dynamic (referring to ecological processes and not goods only). As people impact, and are impacted by, these various ES, the ES concept has the potential to highlight social interdependencies among people that were not explicit or visible beforehand within the traditional common-pool resources framework that focused on social interactions among resource users (Ostrom et al. 1994). For example, if the decision of livestock farmer to increase the number of sheep in a grassland leads to overgrazing, this affects not only the other livestock farmers, but also the beneficiaries of the various impacted ES: lowland water consumers impacted by the loss of water quality, visitors and naturalists who deplore the loss of biodiversity due to degraded habitats, or, at a larger scale, people affected by the climate change induced by the release of stocked carbon (Reed et al. 2009a). 
This notion of social interdependency is critical for the implementation of collective action. Indeed, if people do not feel mutually interdependent, i.e., if they do not feel that they need one another to solve a problem or improve their situation, they are unlikely to invest time and energy in collective action (Leeuwis 2000). Used to highlight hidden social interdependencies, the ES concept could therefore contribute not only to elucidating existing or potential collective actions, but also to increasing people's awareness of their mutual interdependencies, and thereby foster collective action. For instance, by shedding light on social interdependencies associated with key ES for biodiversity-based agriculture, e.g., insect pest regulation, this ES framework can help identify social incentives and obstacles toward agroecological innovations that require coordination among land users.

\section{SOCIAL SCIENCES IN ES RESEARCH: RECENT ADVANCEMENTS AND REMAINING GAPS}

In the last decade, a growing number of scholars have emphasized the need to better understand the social dimension of ES, and several conceptual frameworks have been proposed. Some have stressed the role of societies in the coproduction of ES (Rives et al. 2012, Spangenberg et al. 2014, Bennett et al. 2015, Lescourret et al. 2015, Ruoso et al. 2015) or the relationship between ES and well-being (Coulthard et al. 2011, Daw et al. 2011, Summers et al. 2012). Others have pushed toward the integration of a diversity of value systems in ES valuation, to go beyond economic and monetary valuations based on utilitarian rationalities (Chan et al. 2012, Dendoncker et al. 2014, Martín-López et al. 2014, Raymond et al. 2014), or toward an understanding of the diversity of metaphors framing people's relation to nature, acknowledging that the ES concept is just one metaphor among others (Flint et al. 2013, Raymond et al. 2013, Díaz et al. 2015, Silvertown 2015). Notwithstanding these theoretical and empirical advancements, the understanding of social interdependencies underlying ES dynamics, as well as the role of governance mechanisms based on collective action for ES management, remain underexplored. The conceptual framework that we propose in this paper addresses this gap.

On the operational side, numerous frameworks have been developed to incorporate the ES concept into management and decision-making spheres (Cowling et al. 2008, Daily et al. 2009, de Groot et al. 2010). However, scientific knowledge is often injected in decision-making processes based on an expert mode. Although such expert approaches are effective in many situations, Funtowicz and Ravetz (1993) have suggested that, when scientific uncertainties or social stakes are high, scientists should rather engage in dialogue with decision makers and stakeholders. In this kind of research, called participatory research (Pain and Francis 2003), action research (Todhunter 2001), or transdisciplinary research (Roux et al. 2010), uncertainties and pluralities of values are accepted and managed, and knowledge is coconstructed by scientists, citizens, and decision makers. Such approaches are increasingly advocated in ES research (Reyers et al. 2010, Spangenberg et al. 2015), in particular to assess the social and cultural values of ES (Pereira et al. 2005, Kenter et al. 2011, Berbés-Blázquez 2012, Klain and Chan 2012). Given our focus on collective action and collective decision making at the territorial level, embracing deliberative valuation processes is essential (Raymond et al. 2014). In the proposition we make in this paper to turn our conceptual framework into action, researchers' input becomes an additional ingredient of collective decision-making processes, not only through the sharing of scientific knowledge but also through the development of specific participatory methodologies facilitating deliberative processes (Barreteau et al. 2003, Etienne 2014).

\section{A CONCEPTUAL FRAMEWORK COMBINING ECOSYSTEM SERVICES, SOCIAL INTERDEPENDENCIES, AND COLLECTIVE ACTION}

The conceptual framework we propose (Fig. 1) uses an ES lens to identify and characterize social interdependencies among people so as to reflect on existing or potential collective actions among them. As such, it rests on the following specificities.

First, the framework focuses on social interdependencies among people in a given action arena, around a specific question, issue, or problem. An action arena can include several action situations, referring to "the social space where participants with diverse preferences interact, exchange goods and services, solve problems, dominate one another, or fight (among the many things that individuals do in action arenas)" (Ostrom 2005:14). This means that the application of the framework does not involve identifying an exhaustive list of ES that are produced or perceived on a given territory but rather identifying a subset of ES that are related to a given action situation, a given question, issue, or problem around which people interact or could interact. Furthermore, the action arena can evolve over time, and new stakeholders and ES may thus appear relevant.

Second, although we broadly speak of ES, the framework considers both ES and ecosystem disservices (EDS), the ecological processes that affect human well-being in negative ways, causing harm or costs (Zhang et al. 2007). The picture of a given action situation is indeed incomplete if we look at ecosystems only through their positive impacts. For example, the mere presence of wolves in mountainous areas can be regarded as a cultural ES and as a sign of biodiversity conservation success by many, but sheep farmers from these areas might regard them as a disservice, because wolves can attack their sheep and impact their livelihoods negatively (Boitani 2000, Rescia et al. 2008, Doré 2015).

Third, the framework acknowledges that the same person can play several social roles, e.g., be both provider and beneficiary of a given ES, or beneficiary of several ES (illustrated by the person wearing a hat in Figure 1). A farmer is typically both a coprovider and a beneficiary of provisioning ES such as agricultural production and regulating ES such as insect pest control (Lescourret et al. 2015). The framework also acknowledges that people are inherently multifaceted, valuing a given ES for one dimension of their life and preferring another one for another life dimension. People can even experience internal inconsistencies and dilemmas, when such ES are antagonistic (Duraiappah et al. 2014). For example, a farm advisor may support sheep farming when facing, in a working environment, a conflict between wolves' defenders and sheep farmers, and yet may recognize, for personal reasons, the importance of wolves in the preservation of cultural and natural heritage.

The last key feature of the framework lies in its constructivist perspective. All its components and interactions are socially 
Fig. 1. Framework of analysis of social interdependencies underlying ecosystem services dynamics.

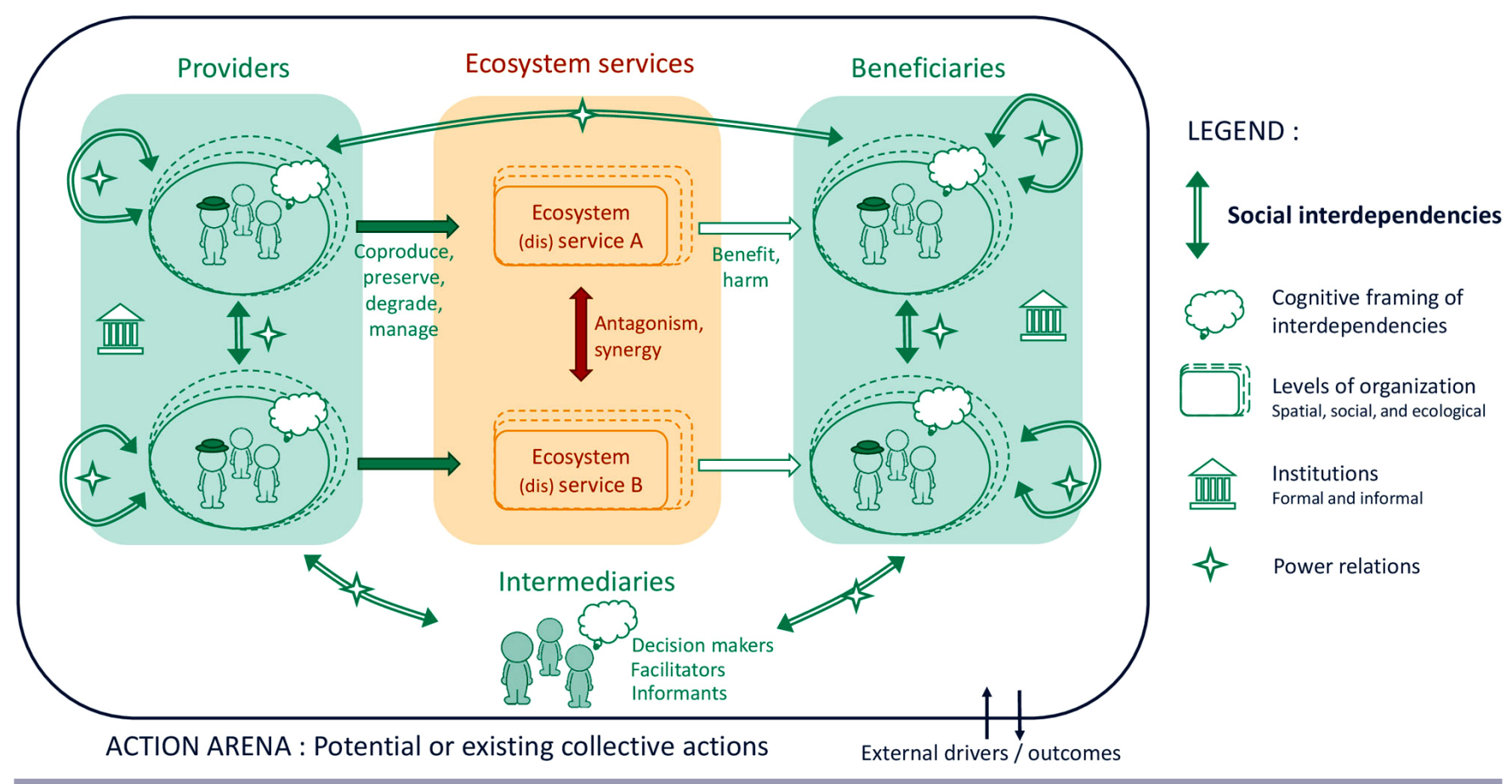

constructed. We do not deny that there are concrete ecological processes at stake, which have a critical influence. Rather, following Latour (2004), we believe that any claim or discourse on ES can be seen as a social construct. For example, an open landscape does not "naturally" or "intrinsically" provide a cultural ES but someone, in a given geographical, cultural, and historical context, attributes a specific patrimonial or aesthetic value to such landscape.

\section{Identify the key ES at stake, their providers and beneficiaries, and the social interdependencies among them}

Figure 1 shows that our framework comprises three social subsystems that interact with an ecological subsystem. The ecological subsystem (central) refers to ES and EDS, i.e., the ecosystem structures, processes, and outputs that humans recognize as obtained from ecosystems and that can support or harm, directly or indirectly, their survival or quality of life. The analysis of this subsystem involves disentangling the key ES and EDS related to the action situation and identifying the ecological processes involved.

The first social subsystem (on the left) includes people who, through their direct actions on ecosystems, contribute to coproducing, degrading, preserving, or managing ES and EDS. We broadly call them ES providers. They are usually people who have rights of access to, and/or use of, the ecosystems, like farmers, herders, or forest owners. The analysis of this subsystem requires the identification of these people and understanding their interests, problems, and practices, and the effects of their practices on ES.

The second social subsystem (on the right) includes people who potentially or actually benefit from, or are harmed by, these ecosystems. We broadly call them ES beneficiaries. They can be people with rights of access to, and/or use of, the ecosystemsthey are then both ES providers and beneficiaries - but they can also be more external people, like tourists enjoying a given landscape or conservationists enjoying the existence of patrimonial species. The analysis of this subsystem involves understanding these people's interests, problems, and practices, the reasons why they value or dislike given ES or EDS, and the consequences for them of an increase or a decrease in ES or EDS.

The third social subsystem (at the bottom) includes people who interact with ES providers and beneficiaries, and who influence decision-making processes regarding ES management. We call them intermediary stakeholders. They include decision makers who can decide upon rules for allocating rights over ecosystems (e.g., a city's mayor or a national park's director), facilitators who foster discussions and negotiations among stakeholders about rules and practices (e.g., the manager of a Natura 2000 site), and informants who share critical knowledge on the functioning of the social-ecological system that can indirectly influence decisions (e.g., a farm advisor or a scientist).

We identify three types of social interdependencies across and within ES providers and beneficiaries. Whereas the ES concept commonly highlights social-ecological interdependencies, i.e., people's dependence and impacts on ecosystems, we focus on people's social interdependencies that are mediated, directly or indirectly, by social-ecological interdependencies (Mathevet et al. 2016). We acknowledge that social interdependencies are often asymmetric, and we broadly use this term to embrace a continuum of situations from one-sided dependency to mutual interdependency. 
Fig. 2. Example of an existing action arena in a Natura 2000 site on the issue of closing landscapes in pastoral agroecosystem in the French Pyrenees.

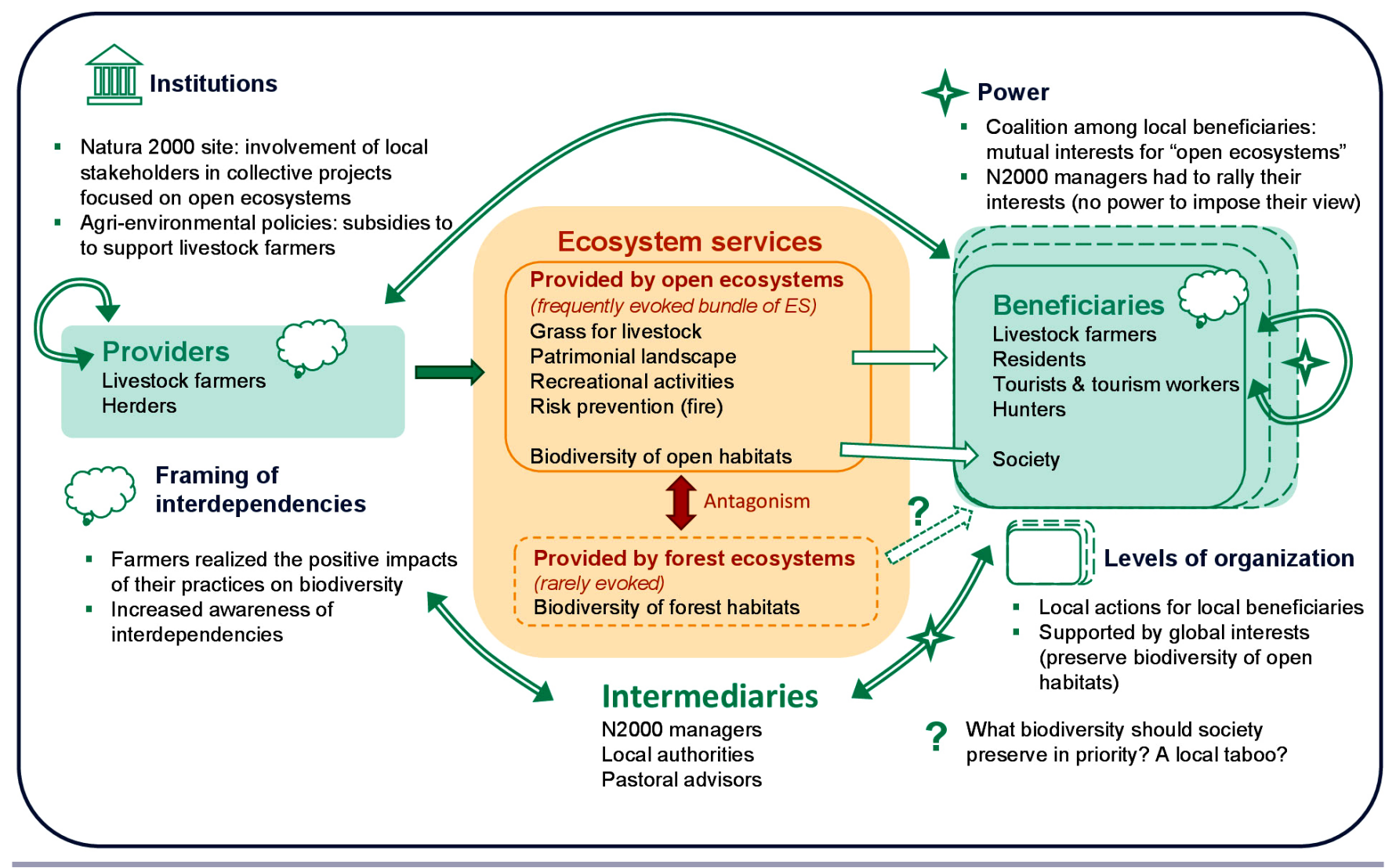

First, there are social interdependencies between ES providers and beneficiaries. These interdependencies are inherently asymmetric: ES beneficiaries are dependent on the actions of ES providers, but ES providers are not necessarily dependent on ES beneficiaries. For example, tourists who enjoy the typical landscape of mountainous pastures are the beneficiaries of a cultural ES that is coproduced by farmers whose sheep graze pastures and prevent spontaneous reforestation, even if they are not aware of it (Villamor et al. 2014).

Second, there are social interdependencies among ES beneficiaries, either among beneficiaries of a given ES, or among beneficiaries of connected ES. Antagonistic ES can lead to conflicting interests between ES beneficiaries, and, conversely, synergetic ES can lead to mutual interests between ES beneficiaries. For example, an open mountainous landscape provides a bundle of ES, including grass for sheep, attractive landscapes for tourists and inhabitants, and specific biodiversity of open ecosystems for conservationists. These actors might thus have a mutual interest in maintaining such open landscapes (Barnaud and Couix, unpublished manuscript; see Fig. 2 for an illustration of this example). The case of interdependencies among the beneficiaries of a single ES is more classical in common-pool resources literature: all beneficiaries have an interest in maintaining the flow of ES, but there can be competition for access to this ES, for example for access to grazing pastures. Intermediary stakeholders often play a key role in the mediation of social interdependencies among ES beneficiaries.

Finally, there are social interdependencies among ES providers, either among providers of a given ES, or among providers of connected ES. Many ES are provided at the landscape level, and their production depends on the actions of several stakeholders who contribute to shaping, degrading, or managing these landscapes (Lescourret et al. 2015). Landscape ecologists have shown for example that landscapes' composition and configuration influence the population dynamics of insect pests and their natural enemies (Bianchi et al. 2006). Biological pest control could then rely on coordination among the farmers and landowners shaping that landscape (Salliou and Barnaud 2017; see Fig. 3 for an illustration of this example). However, providers of landscape ES are not inherently mutually interdependent. They would become interdependent only if they had to provide this ES, either because they value it as beneficiaries (a ban on a given pesticide could, for example, increase farmers' reliance on the ES of biological control), or because they are required to provide it by external beneficiaries (through, for example, a scheme of payments for ES).

\section{Analyze social interdependencies and their characteristics for} collective action

The framework proposes in turn to analyze these social interdependencies through the lens of four dimensions that are 
Fig. 3. Example of a potential action arena on the issue of biological pest control in an apple production area in southwest France.

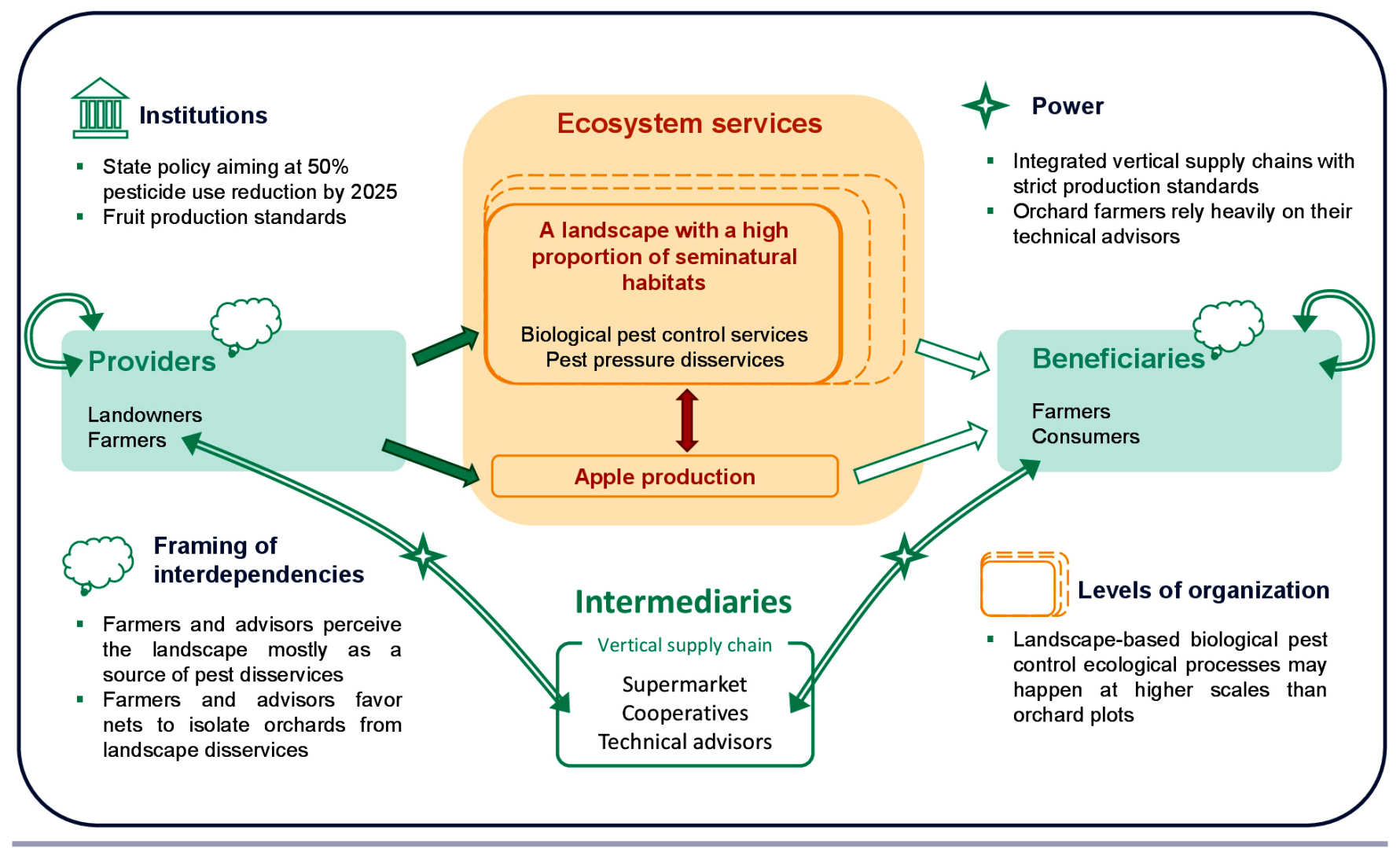

critical for collective action, as shown in Figure 1. The first dimension is the cognitive framing of interdependencies. This requires an analysis of stakeholders' representations of the socialecological and social interdependencies around the key ES under study, to ascertain the degree to which stakeholders perceive themselves as interdependent with other stakeholders, in or outside the territory (Mathevet et al. 2016). This is indeed critical for people's motivation for collective action. For example, if farmers do not perceive the landscape surrounding their farms as a source of natural enemies for biological control, they do not feel interdependent with their neighbors on this matter and have a low motivation for coordination (Fig. 3). Studying cognitive framings of interdependencies is also important for uncovering asymmetric feelings of interdependencies. For example, it often happens that a given stakeholder feels dependent on another regarding a given issue, whereas the latter does not have a reciprocal feeling. This other stakeholder would feel therefore no pressure to engage in a negotiation process about this issue (Leeuwis 2000). It can also happen that it is not in a stakeholder's interest to reveal an existing dependency, because this can lead to the collapse of previous alliances that were efficient and robust only because this dependency was passed over in silence, as, for example, in the case of illegal hunting systems (Mathevet and Mesléard 2002). Finally, it is interesting to observe how these representations evolve over time. In the example of the impact of livestock farming on mountainous landscapes (Fig. 2), the activities of a Natura 2000 site had an impact on farmers' representations: they realized that their farming practices had positive impacts on biodiversity (Barnaud et al. 2015). Some of them assume this new role of ES providers for society and consider positively the associated subsidies.

The second dimension relates to levels of organization. ES are produced at diverse spatial and ecological levels, from soil regeneration at micro-habitat level to climate regulation at global level, and their beneficiaries are located at diverse levels of organization, from individual farmers benefiting from pollination to global society benefiting from biodiversity conservation (Hein et al. 2006, Gómez-Baggethun et al. 2013). The lens of ES uncovers the fact that action arenas, which are commonly composed of local users and managers of resources, could or should be enlarged to people located in distant places or operating at higher governance levels. However, the social distance between the stakeholders of these broadened action arenas can become an obstacle to collective action (Ostrom 2010). When studying the multiple levels involved in ES management, it is also critical to identify potential mismatches between levels of practice and management and levels of ecological processes. This is particularly relevant for agroecology because, as illustrated by the example of insect pest regulation (Fig. 3), mismatches between levels of farmers" practices (farm or field levels) and ecological processes (from intra-field to landscape level) can limit potential agroecological innovations (Pelosi et al. 2010).

The third dimension of our framework focuses on institutions. This implies understanding the existing formal and informal rules governing social interdependencies and regulating the 
provisioning and sharing of ES, i.e., market mechanisms (e.g., supply chains), state-based instruments (e.g., subsidies), and/or local collective actions (Ostrom 2009). It is important to find out how collective actions take place in the multilevel governance structures, and whether the institutional context favors this type of coordination. Although for the management of given ES in given contexts there are clearly identified action arenas and institutions fostering collective action, e.g., watershed committees for water management, or Natura 2000 committees for biodiversity conservation, there are many ES for which there is no existing action arena for collective action. This is the case of insect pest regulation, which is managed mainly at the individual farm level, with vertical interactions with supply chains and technical advisors, and limited space for coordination among farmers (Fig. 3).

Finally, the fourth dimension that we consider critical for collective action and ES management concerns power relations. Analyzing power relations has been a key concern of political ecology, in order to elucidate the driving forces of dominant environmental discourses and environmental governance (Robbins 2004). Such an approach has been increasingly permeating the ES literature (Felipe-Lucia et al. 2015, BerbésBlázquez et al. 2016), and it involves identifying the stakeholders in the action arena who are able to impose their views on specific issues related to ES management, elucidating their sources of power, and identifying the other stakeholders on which they exercise this power. It is particularly important to understand how uneven power relations affect the management of ES and their sustainability. For example, many orchard farmers are highly dependent on cooperatives that impose strict production standards and leave farmers with little room for considering alternatives to pesticides (Fig. 3). Examining power relations is also critical because collective processes can easily be dominated by powerful stakeholders and lead to inequitable outcomes, or reinforce dominant narratives while overlooking other weaker perspectives (Wollenberg et al. 2001, Cornwall 2004, Barnaud and Van Paassen 2013). In the example of the Natura 2000 site (Fig. 2), there is a dominant narrative among local stakeholders on the need to maintain open ecosystems. The environmental managers of the site decided to rally their interests and focus their activities on the biodiversity of open ecosystems, because they had no means (no legal power in particular) to defend a focus on forest biodiversity in face of this local coalition.

\section{AN ACTIONABLE FRAMEWORK}

We have presented in the above section our conceptual framework that uses an ES lens to highlight hidden social interdependencies and shed new light on potential or existing collective actions in agrarian SES. We shall see in this section how this conceptual framework can be turned into action and contribute to enriching collective action in given action arenas. Developing ES frameworks that are actionable, i.e., useful for the actions of local users and managers, is indeed needed. Local decision makers and managers are willing to operationalize the ES concept on the ground (Cowling et al. 2008, Grêt-Regamey et al. 2017), especially through bottom-up approaches involving local stakeholders (see Appendix 1, the case of UNESCO Biosphere Reserves).

To operationalize our framework, we combined it with our experience and knowledge of an existing participatory approach, companion modeling (ComMod), to identify key methodological principles to facilitate concerted ES management in an action research context. ComMod aims to foster collective learning processes among multiple stakeholders (including researchers) on complex SES (Barreteau et al. 2003, Etienne 2014). This approach is based on the coconstruction of simulation models (such as roleplaying games and computer agent-based models) integrating the various stakeholders' representations of the SES, and the use of these simulation models to collectively explore possible future management scenarios (Bousquet and Le Page 2004).

Our methodological suggestions are presented below following key stages of a ComMod process. However, these are suggestions to be used flexibly, rather than different steps of a unified methodology.

- Context analysis, and in particular stakeholder analysis, is an important preliminary step to design and conduct a participatory process, e.g., to select the participants, or to choose the appropriate methodologies (Grimble and Wellard 1997, Barnaud et al. 2008, Reed et al. 2009b, Mathevet et al. 2014). Our conceptual framework can be used as a conceptual basis for such stakeholder analysis, through individual interviews, to characterize the institutional context and identify the key stakeholders in the action arena, their representations, and their relationships. It is very important to assess whether or not stakeholders have an interest in engaging in a collective participatory process (Barreteau et al. 2010). Assessing their feelings of interdependencies is particularly relevant for this purpose because this strongly conditions their motivation for collective action (Antona and Babin 2001). Power analysis is also critical to ensure that powerless stakeholders have the ability to raise and assert their interests in the participatory process (Barnaud and Van Paassen 2013).

- Framing the key issue and the objective of a given participatory process is a critical stage of a participatory process. Following our conceptual framework, this could mean selecting the key ES on which the process will focus by making participants articulate which ES are important to them, why, and according to what values and interests. This stage is particularly sensitive to power asymmetries because the most influential stakeholders can easily orientate the discussions and the framing of the issue toward their own preoccupations.

- Eliciting stakeholders' representations of the SES through individual or collective mapping methods enables the sharing of diverse representations and/or the coconstruction of a shared representation of the system (Becu et al. 2008, Etienne et al. 2011, Mathevet et al. 2011). Our conceptual framework could guide elicitation of stakeholders' representations of the socialecological causal chains underlying the provision of key ES under study, the interactions among these ES, and the social interdependencies linking their providers and beneficiaries.

- Integrating different types of knowledge (empirical, scientific) through coconstructed models is a basic principle of the ComMod approach. It becomes particularly relevant in the case of ES and in the context of agroecological innovations, which can be related to poorly visible, complex, and uncertain ecological processes. Scientific knowledge might critically contribute to revealing cause-effect relationships and social interdependencies 
of which local stakeholders were not aware (Opdam et al. 2016). Conversely, scientists might learn from local stakeholders' empirical knowledge. To continue the insect pest regulation example, a participatory modeling process was conducted to understand and discuss the differences in farmers' and landscape ecologists' representations of the role of landscape in insect pest regulation (Salliou et al. 2017).

- Increasing awareness of interdependencies is a major feature of our proposition. Role-playing games, commonly used in ComMod, have been referred to as one of the most effective ways to convey complexity (Duke 1974). They increase people's awareness of the multiple interdependencies of the system of which they are part (Barnaud et al. 2007, Mathevet et al. 2007, Daré et al. 2014). A role-playing game highlighting ES dynamics and related social interdependencies could therefore contribute to increasing people's awareness of their social interdependencies and thereby influence their willingness to engage in a collective process.

- Exploring scenarios using simulation tools, such as agent-based models or role-playing games, can be effective for testing distinct ES management scenarios, assessing their impacts on different indicators and stakeholders, and highlighting trade-offs in socialecological systems (García-Barrios et al. 2008, Barnaud et al. 2013). Simulation models following our conceptual ES framework would contribute to making explicit some social tradeoffs related to ES and support negotiations on the associated social choices.

- Evaluating the effects of a participatory process is challenging because these effects can range from learning to decision making and action, individually and collectively (Daré et al. 2014). In the case of ES, it would be particularly interesting to assess the added value of the ES concept in the deliberative process, i.e., to find out whether or not the ES lens fostered collective action and framed it in ways that include ecological processes that would have been neglected otherwise, by revealing hidden social interdependencies, or by including new stakeholders in the action arena.

- Reflecting on the role of researchers in a participatory process is critical because they influence the process without necessarily being aware of it. A recent study has shown in particular that researchers can adopt different stances and have different roles in ES research (Crouzat et al. 2018). In our action research proposition, the researchers become part of the action arena, where they can play two different roles: they can act as facilitators that propose tools and methods to foster collective learning among stakeholders, or they can act as informants that take part in the collective learning processes and share their knowledge on the SES, for example on the ecological processes underlying key ES.

\section{CONCLUSION}

In this paper we develop a framework that combines the notions of ES, social interdependencies, and collective action to reflect on the potential and limits of collective action mechanisms for the governance of ES. We suggest using an ES lens to highlight social interdependencies among people who were not visible beforehand within traditional frameworks of natural resource management. These social interdependencies are highly diverse: they can involve distant or proximate people, they can be positive (mutual interest) or negative (conflicting interests), they can be (or not) regulated by existing rules within existing action arenas. All in all, they can be more or less adapted to collective action mechanisms.

Our framework can be used in two complementary ways, either within an analytical research stance or within a participatory action research stance. In the first one, the conceptual framework is applied to characterize ES related social interdependencies and to shed light on potential or existing collective actions. It mobilizes, among others, classic instruments in political ecology like stakeholder and power analysis. In the second stance, this conceptual framework is combined to an existing participatory modeling approach and turned into action, to become actionable. We suggest then using an ES lens to increase people's awareness of their mutual interdependencies and thereby contribute to fostering, framing, or enriching collective action in given action arenas. We now aim to test, implement, and adapt this framework in various agrarian SES and socio-cultural contexts. At the time of writing, four contrasting case studies are under progress, two of which are located in Biosphere Reserves of southern France and northern Catalonia.

This work contributes to the collective research efforts that are made to address the environmental challenges we have to face in the 21 st century, including research on agroecological transitions. Critical issues such as climate change, biodiversity erosion, or water scarcity remind us that we, human beings, are all connected with each other, inserted in complex networks of intertwined ecological processes occurring at multiple scales. To face these challenges, people from different places and sectors need to cooperate. Collective action thinking and practice can therefore be helpful, although E. Ostrom herself acknowledged that adapting the principles of collective action to global issues was a major challenge (Antona and Bousquet 2017). We believe that this is worth trying, and with this paper we attempt to go in this direction, echoing recent ideas and approaches such as empathy across scales $^{[3]}$ and ecological solidarity (Mathevet et al. 2016).

\footnotetext{
${ }^{[1]}$ A common-pool resource is rival (if someone benefits from its use, there is less for someone else) and nonexcludable (it is costly to exclude potential beneficiaries from obtaining benefits from its use). Public goods are nonrival and nonexcludable. Private goods are excludable and rival.

${ }^{[2]}$ Territory refers here to the French notion of territoire, a social and lived space, appropriated and coconstructed by people (Di Méo 1998, Barreteau et al. 2016).

${ }^{[3]}$ The expression "empathy across scales" was introduced by Kate Brown and Carl Folke in their key note speech at the Resilience Conference 2017 hold in Stockholm, from 20 to 23 August.
}

Responses to this article can be read online at: http://www.ecologyandsociety.org/issues/responses. $\mathrm{php} / 9848$

\section{Acknowledgments:}

This research has been funded by the Metaprogram Ecoserv of INRA as an exploratory project named "Secoco : Services Ecosystémiques et Action Collective" coordinated by Cécile 
Barnaud. Nicolas Salliou acknowledges the support of the Metaprogram SMACH of INRA and the region Midi-Pyrénées for his PhD thesis. Clémence Moreau acknowledges the support of the Metaprogram Ecoserv of INRA and the départment SAD of INRA for the support of her PhD thesis. Esteve Corbera acknowledges the support of the Universitat Autonoma de Barcelona-Banco de Santander Talent Retention Programme and notes that this work is contributing to the ICTA-UAB "Unit of Excellence" (MinECo, MDM2015-0552).

\section{LITERATURE CITED}

Adams, W. A., D. Brockington, J. Dyson, and B. Vira. 2003. Managing tragedies: understanding conflict over common pool resources. Science 302:1915-1916. http://dx.doi.org/10.1126/ science. 1087771

Adger, W. N., K. Brown, and E. L. Tompkins. 2005. The political economy of cross-scale networks in resource co-management. Ecology and Society 10(2):9. http://dx.doi.org/10.5751/ES-01465-100209

Agrawal, A., and E. Ostrom. 2001. Collective action, property rights, and decentralization in resource use in India and Nepal. Politics and Society 29:485-514. http://dx.doi.org/10.1177/0032329201029004002

Antona, M., and D. Babin. 2001. Multiple interests accommodation in African forest management projects: between pragmatism and theoretical coherence. International Journal of Agricultural Resources, Governance and Ecology 1(3-4):145-164. http://dx.doi.org/10.1504/IJARGE.2001.000016

Antona, M., and F. Bousquet, editors. 2017. Une troisième voie entre l'État et le marché: Échanges avec Elinor Ostrom. Quae, Versailles, France.

Barnaud, C., and M. Antona. 2014. Deconstructing ecosystem services: uncertainties and controversies around a socially constructed concept. Geoforum 56:113-123. http://dx.doi. org/10.1016/j.geoforum.2014.07.003

Barnaud, C., C. Le Page, P. Dumrongrojwatthana, and G. Trébuil. 2013. Spatial representations are not neutral: lessons from a participatory agent-based modelling process in a land-use conflict. Environmental Modelling \& Software 45:150-159. http:// dx.doi.org/10.1016/i.envsoft.2011.11.016

Barnaud, C., T. Promburom, G. Trébuil, and F. Bousquet. 2007. An evolving simulation/gaming process to facilitate adaptive watershed management in northern mountainous Thailand. Simulation and Gaming 38:398-420. http://dx.doi.

org/10.1177/1046878107300670

Barnaud, C., L. Theil, J.-P. Choisis, and C. Eychenne. 2015. Les services écosystémiques: une notion savante déconnectée des représentations locales? Une analyse des représentations locales de l'élevage en zone agricole défavorisée. Pages 27-50 in $\mathrm{P}$. Beringuier, F. Blot, B. Desailly, and M. Saqalli, editors. Environnement, politiques publiques et pratiques locales. L'Harmattan, Paris, France.

Barnaud, C., G. Trébuil, P. Dumrongrojwatthana, and J. Marie. 2008. Area study prior to companion modelling to integrate multiple interests in upper watershed management of northern Thailand. Southeast Asian Studies 45(4):559-585.
Barnaud, C., and A. Van Paassen. 2013. Equity, power games, and legitimacy: dilemmas of participatory natural resource management. Ecology and Society 18(2):21. http://dx.doi. org/10.5751/ES-05459-180221

Barnaud, C., A. Van Paassen, G. Trébuil, T. Promburom, and F. Bousquet. 2010. Dealing with power games in a companion modelling process: lessons from community water management in Thailand highlands. Journal of Agricultural and Extension Education 16(1):55-74. http://dx.doi.org/10.1080/13892240903533152

Barreteau, O., M. Antona, P. d'Aquino, S. Aubert, S. Boissau, F. Bousquet, W. Dare, M. Etienne, C. Le Page, R. Mathevet, G. Trébuil, and J. Weber. 2003. Our companion modelling approach. Journal of Artificial Societies and Social Simulation 6(2):1.

Barreteau, O., P. W. G. Bots, and K. A. Daniell. 2010. A framework for clarifying "participation" in participatory research to prevent its rejection for the wrong reasons. Ecology and Society 15(2):1. http://dx.doi.org/10.5751/ES-03186-150201

Barreteau, O., D. Giband, M. Schoon, J. Cerceau, F. DeClerck, S. Ghiotti, T. James, V. A. Masterson, R. Mathevet, S. Rode, F. Ricci, and C. Therville. 2016. Bringing together social-ecological system and territoire concepts to explore nature-society dynamics. Ecology and Society 21(4):42. http://dx.doi.org/10.5751/ ES-08834-210442

Becu, N., A. Neef, P. Schreinemachers, and C. Sangkapitux. 2008. Participatory computer simulation to support collective decisionmaking: potential and limits of stakeholder involvement. Land Use Policy 25(4):498-509. http://dx.doi.org/10.1016/j. landusepol.2007.11.002

Bennett, E. M., W. Cramer, A. Begossi, G. Cundill, S. Díaz, B. N. Egoh, I. R. Geijzendorffer, C. B. Krug, S. Lavorel, E. Lazos, L. Lebel, B. Martín-López, P. Meyfroidt, H. A. Mooney, J. L. Nel, U. Pascual, K. Payet, N. P. Harguindeguy, G. D. Peterson, A.-H. Prieur-Richard, B. Reyers, P. Roebeling, R. Seppelt, M. Solan, P. Tschakert, T. Tscharntke, B. L. Turner II, P. H. Verburg, E. F. Viglizzo, P. C. L. White, and G. Woodward. 2015. Linking biodiversity, ecosystem services, and human well-being: three challenges for designing research for sustainability. Current Opinion in Environmental Sustainability 14:76-85. http://dx.doi. org/10.1016/j.cosust.2015.03.007

Berbés-Blázquez, M. 2012. A participatory assessment of ecosystem services and human wellbeing in rural Costa Rica using photo-voice. Environmental Management 49(4):862-875. http:// dx.doi.org/10.1007/s00267-012-9822-9

Berbés-Blázquez, M., J. A. González, and U. Pascual. 2016. Towards an ecosystem services approach that addresses social power relations. Current Opinion in Environmental Sustainability 19:134-143. http://dx.doi.org/10.1016/j.cosust.2016.02.003

Berkes, F. 1989. Common property resources; ecology and community-based sustainable development. Belhaven Press, London, UK.

Bianchi, F. J. J. A., C. J. H. Booij, and T. Tscharntke. 2006. Sustainable pest regulation in agricultural landscapes: a review on landscape composition, biodiversity and natural pest control. Proceedings of the Royal Society B 273:1715-1727. http://dx.doi. org/10.1098/rspb.2006.3530 
Boitani, L. 2000. Action plan for the conservation of wolves (Canis lupus) in Europe. Council of Europe, Strasbourg, France.

Borrini-Feyerabend, G., M. Pimbert, M. T. Farvar, A. Kothari, and Y. Renard. 2004. Sharing power. Learning by dowing in comanagement of natural resources throughout the world. IIED and IUCN/CEESP/CMWG, Cenesta, Tehran.

Bousquet, F., and C. Le Page. 2004. Multi-agent simulations and ecosystem management: a review. Ecological Modelling 176:313-332. http://dx.doi.org/10.1016/j.ecolmodel.2004.01.011

Chan, K. M. A., T. Satterfield, and J. Goldstein. 2012. Rethinking ecosystem services to better address and navigate cultural values. Ecological Economics 74:8-18. http://dx.doi.org/10.1016/j. ecolecon.2011.11.011

Cornwall, A. 2004. Spaces for transformation? Reflections on issues of power and difference in participation in development. Pages 75-91 in S. Hickey and G. Mohan, editors. Participation: from tyranny to transformation? Exploring approaches to participation in development. Zed Books, London, UK.

Coulthard, S., D. Johnson, and J. A. McGregor. 2011. Poverty, sustainability and human wellbeing: a social wellbeing approach to the global fisheries crisis. Global Environmental Change 21 (2):453-463. http://dx.doi.org/10.1016/j.gloenvcha.2011.01.003

Cowling, R. M., B. Egoh, A. T. Knight, P. J. O’Farrell, B. Reyers, M. Rouget, D. J. Roux, A. Welz, and A. Wilhelm-Rechman. 2008. An operational model for mainstreaming ecosystem services for implementation. Proceedings of the National Academy of Sciences 105(28):9483-9488. http://dx.doi.org/10.1073/pnas.0706559105

Crouzat, E., I. Arpin, L. Brunet, M. J. Colloff, F. Turkelboom, and S. Lavorel. 2018. Researchers must be aware of their roles at the interface of ecosystem services science and policy. $A M B I O$ 47:97-105. http://dx.doi.org/10.1007/s13280-017-0939-1

Daily, G. C., S. Polasky, J. Goldstein, P. M. Kareiva, H. A. Mooney, L. Pejchar, T. H. Ricketts, J. Salzman, and R. Shallenberger. 2009. Ecosystem services in decision making: time to deliver. Frontiers in Ecology and the Environment 7(1):21-28. http://dx.doi.org/10.1890/080025

Daré, W., A. Van Paassen, R. Ducrot, R. Mathevet, J. Queste, G. Trébuil, C. Barnaud, and E. Lagabrielle. 2014. Learning about interdependencies and dynamics. Pages 233-262 in M. Étienne, editor. Companion modelling. Springer, Dordrecht, The Netherlands. http://dx.doi.org/10.1007/978-94-017-8557-0 10

Daw, T., K. Brown, S. Rosendo, and R. Pomeroy. 2011. Applying the ecosystem services concept to poverty alleviation: the need to disaggregate human well-being. Environmental Conservation 38 (04):370-379. http://dx.doi.org/10.1017/S0376892911000506

de Groot, R. S., R. Alkemade, L. Braat, L. Hein, and L. Willemen. 2010. Challenges in integrating the concept of ecosystem services and values in landscape planning, management and decision making. Ecological Complexity 7(3):260-272. http://dx.doi. org/10.1016/j.ecocom.2009.10.006

Dendoncker, N., H. Keune, S. Jacobs, and E. Gomez-Baggethum. 2014. Inclusive ecosystem service valuation. Pages 3-12 in S. Jacobs, N. Dendoncker, and H. Keune, editors. Ecosystem services: global issues, local practices. Elsevier, San Diego, California, USA. http://dx.doi.org/10.1016/B978-0-12-419964-4.00001-9
Depres, C., G. Grolleau, and N. Mzoughi. 2008. Contracting for environmental property rights: the case of Vittel. Economica 75 (299):412-434. http://dx.doi.org/10.1111/j.1468-0335.2007.00620. $\underline{x}$

Di Méo, G. 1998. Géographie sociale et territoire. Nathan Université, Paris, France.

Díaz, S., S. Demissew, J. Carabias, C. Joly, M. Lonsdale, N. Ash, A. Larigauderie, J. R. Adhikari, S. Arico, A. Báldi, A. Bartuska, I. A. Baste, A. Bilgin, E. Brondizio, K. M. A. Chan, V. E. Figueroa, A. Duraiappah, M. Fischer, R. Hill, T. Koetz, P. Leadley, P. Lyver, G. M. Mace, B. Martin-Lopez, M. Okumura, D. Pacheco, U. Pascual, E. S. Pérez, B. Reyers, E. Roth, O. Saito, R. J. Scholes, N. Sharma, H. Tallis, R. Thaman, R. Watson, T. Yahara, Z. A. Hamid, C. Akosim, Y. Al-Hafedh, R. Allahverdiyev, E. Amankwah, S. T. Asah, Z. Asfaw, G. Bartus, L. A. Brooks, J. Caillaux, G. Dalle, D. Darnaedi, A. Driver, G. Erpul, P. EscobarEyzaguirre, P. Failler, A. M. M. Fouda, B. Fu, H. Gundimeda, S Hashimoto, F. Homer, S. Lavorel, G. Lichtenstein, W. A. Mala, W. Mandivenyi, P. Matczak, C. Mbizvo, M. Mehrdadi, J. P. Metzger, J. B. Mikissa, H. Moller, H. A. Mooney, P. Mumby, H. Nagendra, C. Nesshover, A. A. Oteng-Yeboah, G. Pataki, M. Roué, J. Rubis, M. Schultz, P. Smith, R. Sumaila, K. Takeuchi, S. Thomas, M. Verma, Y. Yeo-Chang, and D. Zlatanova. 2015. The IPBES conceptual framework - connecting nature and people. Current Opinion in Environmental Sustainability 14:1-16. http:// dx.doi.org/10.1016/j.cosust.2014.11.002

Doré, A. 2015. Attention aux loups! L'ambivalence de la menace et de sa mesure. Ethnologie française 45:45-54. http://dx.doi. org/10.3917/ethn.151.0045

Duke, R. D. 1974. Gaming: the future's language. SAGE, Halsted Press, New York, New York, USA.

Duraiappah, A. K., S. T. Asah, E. S. Brondizio, N. Kosoy, P. J. O'Farrell, A.-H. Prieur-Richard, S. M. Subramanian, and K. Takeuchi. 2014. Managing the mismatches to provide ecosystem services for human well-being: a conceptual framework for understanding the New Commons. Current Opinion in Environmental Sustainability 7:94-100. http://dx.doi.org/10.1016/ j.cosust.2013.11.031

Duru, M., O. Therond, and M. Fares. 2015. Designing agroecological transitions: a review. Agronomy for Sustainable Development 35(4):1237-1257. http://dx.doi.org/10.1007/s13593-015-0318$\underline{\mathrm{X}}$

Etienne, M., editor. 2014. Companion modelling. A participatory approach to support sustainable development. Springer, Dordrecht, The Netherlands.

Etienne, M., D. R. Du Toit, and S. Pollard. 2011. ARDI: a coconstruction method for participatory modeling in natural resources management. Ecology and Society 16(1):44. http://dx. doi.org/10.5751/ES-03748-160144

Felipe-Lucia, M. R., B. Martín-López, S. Lavorel, L. BerraqueroDíaz, J. Escalera-Reyes, and F. A. Comín. 2015. Ecosystem services flows: why stakeholders' power relationships matter. PLoS ONE 10(7):e0132232. http://dx.doi.org/10.1371/journal. pone. 0132232

Fletcher, R., and J. Breitling. 2012. Market mechanism or subsidy in disguise? Governing payment for environmental services in 
Costa Rica. Geoforum 43(3):402-411. http://dx.doi.org/10.1016/j. geoforum.2011.11.008

Flint, C. G., I. Kunze, A. Muhar, Y. Yoshida, and M. Penker. 2013. Exploring empirical typologies of human-nature relationships and linkages to the ecosystem services concept. Landscape and Urban Planning 120:208-217. http://dx.doi. org/10.1016/j.landurbplan.2013.09.002

Folke, C., S. Carpenter, T. Elmqvist, L. Gunderson, C. S. Holling, and B. Walker. 2002. Resilience and sustainable development: building adaptive capacity in a world of transformations. AMBIO 31(5):437-440. http://dx.doi.org/10.1579/0044-7447-31.5.437

Funtowicz, S. O., and J. R. Ravetz. 1993. Science for the postnormal age. Futures 25:739-755. http://dx.doi.org/10.1016/0016-3287 (93)90022-L

García-Barrios, L. E., E. N. Speelman, and M. S. Pimm. 2008. An educational simulation tool for negotiating sustainable natural resource management strategies among stakeholders with conflicting interests. Ecological Modelling 210(1-2):115-126. http://dx.doi.org/10.1016/j.ecolmodel.2007.07.009

Gómez-Baggethun, E., E. Kelemen, B. Martín-López, I. Palomo, and C. Montes. 2013. Scale misfit in ecosystem service governance as a source of environmental conflict. Society \& Natural Resources 26(10):1202-1216. http://dx.doi.org/10.1080/08941920.2013.820817

Grêt-Regamey, A., E. Sirén, S. H. Brunner, and B. Weibel. 2017. Review of decision support tools to operationalize the ecosystem services concept. Ecosystem Services 26(Part B):306-315. http:// dx.doi.org/10.1016/j.ecoser.2016.10.012

Grimble, R., and K. Wellard. 1997. Stakeholder methodologies in natural resource management: a review of principles, contexts, experiences and opportunities. Agricultural Systems 55 (2):173-193. http://dx.doi.org/10.1016/S0308-521X(97)00006-1

Harrington, R., C. Anton, T. P. Dawson, F. de Bello, C. K. Feld, J. R. Haslett, T. Kluvánkova-Oravská, A. Kontogianni, S. Lavorel, G. W. Luck, M. D. A. Rounsevell, M. J. Samways, J. Settele, M. Skourtos, J. H. Spangenberg, M. Vandewalle, M. Zobel, and P. A. Harrison. 2010. Ecosystem services and biodiversity conservation: concepts and a glossary. Biodiversity and Conservation 19(10):2773-2790. http://dx.doi.org/10.1007/ s10531-010-9834-9

Hein, L., K. van Koppen, R. S. de Groot, and E. C. van Ierland. 2006. Spatial scales, stakeholders and the valuation of ecosystem services. Ecological Economics 57(2):209-228. http://dx.doi. org/10.1016/j.ecolecon.2005.04.005

Kenter, J. O., T. Hyde, M. Christie, and I. Fazey. 2011. The importance of deliberation in valuing ecosystem services in developing countries-evidence from the Solomon Islands. Global Environmental Change 21(2):505-521. http://dx.doi.org/10.1016/ j.gloenvcha.2011.01.001

Kerr, J. M., M. Vardhan, and R. Jindal. 2014. Incentives, conditionality and collective action in payment for environmental services. International Journal of the Commons 8(2):595-616. http://dx.doi.org/10.18352/ijc.438

Klain, S. C., and K. M. A. Chan. 2012. Navigating coastal values: participatory mapping of ecosystem services for spatial planning.
Ecological Economics 82:104-113. http://dx.doi.org/10.1016/j. ecolecon.2012.07.008

Kosoy, N., and E. Corbera. 2010. Payments for ecosystem services as commodity fetishism. Ecological Economics 69(6):1228-1236. http://dx.doi.org/10.1016/j.ecolecon.2009.11.002

Latour, B. 2004. Politics of nature. How to bring the sciences into democracy. Harvard University Press, London, UK.

Leach, M., and J. Fairhead. 2001. Plural perspectives and institutionnal dynamics: challenges for local forest management. Agricultural Resources, Governance and Ecology 1(3/4):223-242.

Leeuwis, C. 2000. Reconceptualizing participation for sustainable rural development: towards a negotiation approach. Development and Change 31:931-959. http://dx.doi.org/10.1111/1467-7660.00184

Lescourret, F., D. Magda, G. Richard, A.-F. Adam-Blondon, M. Bardy, J. Baudry, I. Doussan, B. Dumont, F. Lefèvre, I. Litrico, R. Martin-Clouaire, B. Montuelle, S. Pellerin, M. Plantegenest, E. Tancoigne, A. Thomas, H. Guyomard, and J.-F. Soussana. 2015. A social-ecological approach to managing multiple agroecosystem services. Current Opinion in Environmental Sustainability 14:68-75. http://dx.doi.org/10.1016/j.cosust.2015.04.001

Maris, V. 2014. Nature à vendre. Les limites des services écosystémiques. Quae, Versailles, France. http://dx.doi.org/10.3917/ quae.maris.2014.01

Martín-López, B., E. Gómez-Baggethun, M. García-Llorente, and C. Montes. 2014. Trade-offs across value-domains in ecosystem services assessment. Ecological Indicators 37, Part A:220-228. http://dx.doi.org/10.1016/j.ecolind.2013.03.003

Mathevet, R., M. Antona, C. Barnaud, C. Fourage, G. Trébuil, and S. Aubert. 2014. Contexts and dependencies in the ComMod Processes. Pages 103-125 in M. Étienne, editor. Companion modelling. Springer, Dordrecht, The Netherlands. http://dx.doi. org/10.1007/978-94-017-8557-0_5

Mathevet, R., M. Etienne, T. Lynam, and C. Calvet. 2011. Water management in the Camargue Biosphere Reserve: insights from comparative mental models analysis. Ecology and Society 16 (1):43. http://dx.doi.org/10.5751/ES-04007-160143

Mathevet, R., C. Le Page, M. Etienne, G. Lefebvre, B. Poulin, G. Gigot, S. Proréol, and A. Mauchamp. 2007. BUTORSTAR: a role-playing game for collective awareness of wise reedbed use. Simulation \& Gaming 38(2):233-262. http://dx.doi. org/10.1177/1046878107300665

Mathevet, R., and F. Mesléard. 2002. The origins and functioning of the private wildfowling lease system in a major Mediterranean wetland: the Camargue (Rhone delta, southern France). Land Use Policy 19(4):277-286. http://dx.doi.org/10.1016/S0264-8377 (02)00025-X

Mathevet, R., J. D. Thompson, C. Folke, and F. S. Chapin III. 2016. Protected areas and their surrounding territory: socioecological systems in the context of ecological solidarity. Ecological Applications 26(1):5-16. http://dx.doi.org/10.1890/14-0421

Meinzen-Dick, R., M. DiGregorio, and N. McCarthy. 2004. Methods for studying collective action in rural development. Agricultural Systems 82(3):197-214. http://dx.doi.org/10.1016/j. agsy.2004.07.006 
Millennium Ecosystem Assessment (MEA). 2005. Ecosystems and human well-being: current states and trends. Island Press, Washington, D.C., USA.

Muradian, R. 2013. Payments for ecosystem services as incentives for collective action. Society \& Natural Resources 26 (10):1155-1169. http://dx.doi.org/10.1080/08941920.2013.820816

Muradian, R., E. Corbera, U. Pascual, N. Kosoy, and P. H. May. 2010. Reconciling theory and practice: an alternative conceptual framework for understanding payments for environmental services. Ecological Economics 69(6):1202-1208. http://dx.doi. org/10.1016/j.ecolecon.2009.11.006

Muradian, R., and L. Rival. 2012. Between markets and hierarchies: the challenge of governing ecosystem services. Ecosystem Services 1:93-100. http://dx.doi.org/10.1016/j. ecoser.2012.07.009

Olson, M. 1965. Logic of collective action public goods and the theory of groups. Harvard University Press, Cambridge, Massachusetts, USA.

Opdam, P., I. Coninx, A. Dewulf, E. Steingröver, C. Vos, and M. van der Wal. 2016. Does information on landscape benefits influence collective action in landscape governance? Current Opinion in Environmental Sustainability 18:107-114. http://dx.doi. org/10.1016/j.cosust.2015.12.006

Ostrom, E. 1990. Governing the commons: the evolution of institutions for collective actions. Cambridge University Press, Cambridge, UK. http://dx.doi.org/10.1017/CBO9780511807763

Ostrom, E. 2005. Understanding institutional diversity. Princeton University Press, Princeton, New Jersey, USA.

Ostrom, E. 2009. A general framework for analyzing sustainability of social-ecological systems. Science 325 (5939):419-422. http://dx.doi.org/10.1126/science.1172133

Ostrom, E. 2010. Beyond markets and states: polycentric governance of complex economic systems. Transnational Corporations Review 2(2):1-12. http://dx.doi.org/10.1080/19186$\underline{444.2010 .11658229}$

Ostrom, E., R. Gardner, and J. Walker. 1994. Rules, games \& common-pool resources. University of Michigan Press, Ann Arbor, Michigan, USA. http://dx.doi.org/10.3998/mpub.9739

Pahl-Wostl, C., M. Craps, A. Dewulf, E. Mostert, D. Tabara, and T. Taillieu. 2007. Social learning and water resources management. Ecology and Society 12(2):5. http://dx.doi. org/10.5751/ES-02037-120205

Pain, R., and P. Francis. 2003. Reflections on participatory research. Area 35:46-54. http://dx.doi.org/10.1111/1475-4762.00109

Pelosi, C., M. Goulard, and G. Balent. 2010. The spatial scale mismatch between ecological processes and agricultural management: do difficulties come from underlying theoretical frameworks? Agriculture, Ecosystems \& Environment 139 (4):455-462. http://dx.doi.org/10.1016/j.agee.2010.09.004

Pereira, E., C. Queiroz, H. Pereira, and L. Vicente. 2005. Ecosystem services and human well-being: a participatory study in a mountain community in Portugal. Ecology and Society 10 (2):14. http://dx.doi.org/10.5751/ES-01353-100214
Rawls, J. 1997. Théorie de la justice. Seuil, Paris, France.

Raymond, C. M., J. O. Kenter, T. Plieninger, N. J. Turner, and K. A. Alexander. 2014. Comparing instrumental and deliberative paradigms underpinning the assessment of social values for cultural ecosystem services. Ecological Economics 107:145-156. http://dx.doi.org/10.1016/j.ecolecon.2014.07.033

Raymond, C. M., G. G. Singh, K. Benessaiah, J. R. Bernhardt, J. Levine, H. Nelson, N. J. Turner, B. Norton, J. Tam, and K. M. A. Chan. 2013. Ecosystem services and beyond: using multiple metaphors to understand human-environment relationships. BioScience 63(7):536-546. http://dx.doi.org/10.1525/bio.2013.63.7.7

Reed, M. S., A. Bonn, W. Slee, N. Beharry-Borg, J. Birch, I. Brown, T. P. Burt, D. Chapman, P. J. Chapman, G. D. Clay, S. J. Cornell, E. D. G. Fraser, J. H. Glass, J. Holden, J. A. Hodgson, K. Hubacek, B. Irvine, N. Jin, M. J. Kirkby, W. E. Kunin, O. Moore, D. Moseley, C. Prell, M. F. Price, C. H. Quinn, S. Redpath, C. Reid, S. Stagl, L. C. Stringer, M. Termansen, S. Thorp, W. Towers, and F. Worrall. 2009a. The future of the uplands. Land Use Policy 26 (Supplement 1):S204-S216. http://dx.doi.org/10.1016/j. landusepol.2009.09.013

Reed, M. S., A. Graves, N. Dandy, H. Posthumus, K. Hubacek, J. Morris, C. Prell, C. H. Quinn, and L. C. Stringer. 2009b. Who's in and why? A typology of stakeholder analysis methods for natural resource management. Journal of Environmental Management 90(5):1933-1949. http://dx.doi.org/10.1016/j. jenvman.2009.01.001

Rescia, A. J., A. Pons, I. Lomba, C. Esteban, and J. W. Dover. 2008. Reformulating the social-ecological system in a cultural rural mountain landscape in the Picos de Europa region (northern Spain). Landscape and Urban Planning 88(1):23-33. http://dx.doi. org/10.1016/j.landurbplan.2008.08.001

Reyers, B., D. J. Roux, and P. J. O'Farrell. 2010. Can ecosystem services lead ecology on a transdisciplinary pathway? Environmental Conservation 37(4):501-511. http://dx.doi.org/10.1017/ $\underline{\mathrm{S} 0376892910000846}$

Rives, F., M. Antona, and S. Aubert. 2012. Social-ecological functions and vulnerability framework to analyze forest policy reforms. Ecology and Society 17(4):21. http://dx.doi.org/10.5751/ ES-05182-170421

Robbins, P. 2004. Political ecology: a critical introduction. Blackwell, Malden, Massachusetts, USA.

Rodríguez, J. P., T. D. Beard, Jr., E. M. Bennett, G. S. Cumming, S. Cork, J. Agard, A. P. Dobson, and G. D. Peterson. 2006. Tradeoffs across space, time, and ecosystem services. Ecology and Society 11(1):28. http://dx.doi.org/10.5751/ES-01667-110128

Roux, D. J., R. J. Stirzaker, C. M. Breen, E. C. Lefroy, and H. P. Cresswell. 2010. Framework for participative reflection on the accomplishment of transdisciplinary research programs. Environmental Science \& Policy 13(8):733-741. http://dx.doi. org/10.1016/j.envsci.2010.08.002

Ruoso, L.-E., R. Plant, P. Maurel, C. Dupaquier, P. K. Roche, and M. Bonin. 2015. Reading ecosystem services at the local scale through a territorial approach: the case of peri-urban agriculture in the Thau Lagoon, Southern France. Ecology and Society 20 (3):11. http://dx.doi.org/10.5751/ES-07694-200311 
Salliou, N., and C. Barnaud. 2017. Landscape and biodiversity as new resources for agro-ecology? Insights from farmers' perspectives. Ecology and Society 22(2):16. http://dx.doi. org/10.5751/ES-09249-220216

Salliou, N., C. Barnaud, A. Vialatte, and C. Monteil. 2017. A participatory Bayesian Belief Network approach to explore ambiguity among stakeholders about socio-ecological systems. Environmental Modelling \& Software 96:199-209. http://dx.doi. org/10.1016/j.envsoft.2017.06.050

Scott, J., and G. Marshall. 2009. A dictionary of sociology. Oxford University Press, Oxford, UK. http://dx.doi.org/10.1093/ acref/9780199533008.001.0001

Shapiro-Garza, E. 2013. Contesting the market-based nature of Mexico's national payments for ecosystem services programs: four sites of articulation and hybridization. Geoforum 46:5-15. http://dx.doi.org/10.1016/j.geoforum.2012.11.018

Silvertown, J. 2015. Have ecosystem services been oversold? Trends in Ecology \& Evolution 30(11):641-648. http://dx.doi. org/10.1016/j.tree.2015.08.007

Spangenberg, J. H., C. Görg, and J. Settele. 2015. Stakeholder involvement in ESS research and governance: between conceptual ambition and practical experiences - risks, challenges and tested tools. Ecosystem Services 16:201-211. http://dx.doi.org/10.1016/ j.ecoser.2015.10.006

Spangenberg, J. H., C. Görg, D. T. Truong, V. Tekken, J. V. Bustamante, and J. Settele. 2014. Provision of ecosystem services is determined by human agency, not ecosystem functions. Four case studies. International Journal of Biodiversity Science, Ecosystem Services \& Management 10(1):40-53. http://dx.doi. org/10.1080/21513732.2014.884166

Spash, C. L. 2011. Terrible economics, ecosystems and banking. Environmental Values 20(2):141-145. http://dx.doi. org/10.3197/096327111X12997574391562

Stallman, H. R. 2011. Ecosystem services in agriculture: determining suitability for provision by collective management. Ecological Economics 71:131-139. http://dx.doi.org/10.1016/j. ecolecon.2011.08.016

Sullivan, S. 2009. Green capitalism, and the cultural poverty of constructing nature as service provider. Radical Anthropology 2009-2010(3):18-27.

Summers, J. K., L. M. Smith, J. L. Case, and R. A. Linthurst. 2012. A review of the elements of human well-being with an emphasis on the contribution of ecosystem services. AMBIO 41 (4):327-340. http://dx.doi.org/10.1007/s13280-012-0256-7

Todhunter, C. 2001. Undertaking action research: negotiating the road ahead. Social Research Update 34.

Villamor, G. B., I. Palomo, C. A. López Santiago, E. OterosRozas, and J. Hill. 2014. Assessing stakeholders' perceptions and values towards social-ecological systems using participatory methods. Ecological Processes 3(1):22. http://dx.doi.org/10.1186/ $\underline{\text { s13717-014-0022-9 }}$
Wollenberg, E., J. Anderson, and D. Edmunds. 2001. Pluralism and the less powerful: accommodating multiple interests in local forest management. International Journal of Agricultural Resources, Governance and Ecology 1(3/4):199-222. http://dx.doi. org/10.1504/IJARGE.2001.000012

Zhang, W., T. H. Ricketts, C. Kremen, K. Carney, and S. M. Swinton. 2007. Ecosystem services and dis-services to agriculture. Ecological Economics 64:253-260. http://dx.doi.org/10.1016/j. ecolecon.2007.02.024 


\section{What is a Biosphere Reserve?}

A biosphere reserve (BR) is an international designation by UNESCO in the Man And Biosphere (MAB) program. A BR includes one or several protected areas and their surrounding landscape to combine both biodiversity conservation and sustainable/wise use of natural resources. A BR is a place where local communities are involved in management through dialogue and concerted multi-stakeholder approaches. Through monitoring, research, education, and training, BRs aim to develop and demonstrate sound sustainable development practices and policies. In 2017, there are 669 BRs in 120 countries all over the world, connected through international, regional, and national networks promoting knowledge sharing and exchanges of experiences.

\section{How is the ES concept operationalized in Biosphere Reserves?}

Since 2013, the ES concept has been integrated in the requisite forms for BR creation or revision. Coordinators are requested to address the following:

"- 12.1 If possible, identify the ecosystem services provided by each ecosystem of the biosphere reserve and the beneficiaries of these services.

- 12.2 Specify whether indicators of ecosystem services are used to evaluate the three functions (conservation, development, and logistic) of biosphere reserves. If yes, which ones and give details.

- 12.3 Describe biodiversity involved in the provision of ecosystems services in the biosphere reserve (e.g. species or groups of species involved).

- 12.4 Specify whether any ecosystem services assessment has been done for the proposed biosphere reserve".

This requires inventory approaches, with objective ES assessments, rather than deliberations among people about ES management.

\section{What are BR managers' needs regarding the ES concept?}

Some BR coordinators are uneasy with the ES concept, the utilitarian perception of nature and the monetary valuations it embodies. Others perceive a potential to communicate about society's dependence on ecosystems. All in all, there is a need to operationalize the concept in a way that fits with MAB principles, especially bottom-up and territorial approaches involving local stakeholders. Since 2015, the French MAB committee has fostered a reflection involving researchers and $B R$ managers on how to use the ES concept for $B R$ management.

\section{Why do research on ES in partnership with Biosphere Reserves?}

The conceptual framework presented in this paper is the working basis of an action research project conducted in partnership with two Biosphere Reserves: Cévennes in southern France and Montseny in Catalonia, Spain. BR managers contributed to the elaboration of the framework and are participating in its implementation on the ground (work in progress). Partnerships with BRs are particularly relevant for implementing transdisciplinary research and producing actionable knowledge aimed at sustainable management of socio-ecological systems. 